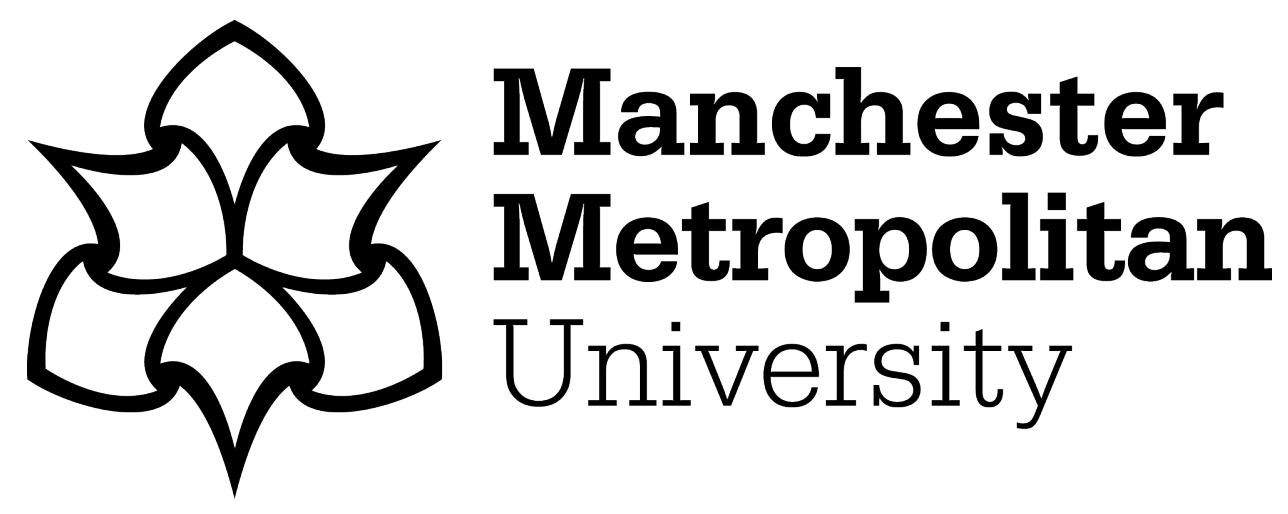

Bamford, D, Hannibal, CL, Kauppi, K and Dehe, B (2018) Sports Operations Management: Examining the Relationship Between Environmental Uncertainty and Quality Management Orientation. European Sport Management Quarterly, 18 (5). pp. 563-582. ISSN 1618-4742

Downloaded from: https://e-space.mmu.ac.uk/620613/

Version: Accepted Version

Publisher: Taylor \& Francis (Routledge)

DOI: https://doi.org/10.1080/16184742.2018.1442486

Please cite the published version 


\title{
Sports operations management: Examining the relationship between environmental uncertainty and quality management orientation
}

\begin{abstract}
Research question: The outcome of a sporting competition is uncertain and one of the key reasons for the sustained popularity of spectator sport. Whilst unique and exciting, this context poses challenges for the management of the sporting experience as there is no control over the outcome of the competition; a disappointing result on-field may translate to a disappointing overall experience for the spectators. We wish to understand if and how quality management practices are used in off-field operations to mitigate on-field uncertainty, and thus have greater control over spectator perception of the sporting experience.
\end{abstract}

Research methods: A multi-country survey of operations managers of sporting stadia in the United Kingdom, United States, Canada, Australia and New Zealand was conducted. We operationalize environmental uncertainty as spectator co-creation and enforced collaboration, and assess quality management orientation from both a customer and process perspective. Linear regression is used for data analysis.

Results and Findings: Surprisingly, we find that environmental uncertainty does not encourage the orientation of quality management practices towards the customer. Instead, we find a greater application of process focus. In considering sporting fans as passive customers rather than active co-creators of value, quality management practices seem to have skewed towards process rather than person. 
Implications: Customer satisfaction appears as secondary to process performance in the sample of stadia examined. This is in contrast to studies that have encouraged a focus on the customer in contexts of environmental uncertainty. We suggest a renewed focus on the customer for the longevity of sporting stadia.

Keywords: quality management, operations, customer, process

\section{Introduction}

Sport is ubiquitous across the world. Involving millions of fans, multi-million dollar salaries and lucrative television contracts, it constitutes a major economic activity in many countries (Sainam, Balasubramanian \& Bayus, 2010). In North America alone the sports industry is expected to grow at an annual rate of 3.5\% from \$63.9 billion in 2015 to $\$ 75.7$ billion in 2020 (PWC, 2016). There are concerns about growth and the saturation of the market, and hence sport operations managers must respond to the ever more competitive market environment by encouraging fans to attend games as spectators (Theodorakis, Koustelios, Robinson \& Barlas, 2009). One response has been to consider service quality from the perspective of the sport spectator (Ko \& Pastore, 2007). Customer evaluation of service quality is influenced by expectation, process quality and output quality (Abdullah \& Rozario, 2009). In addition, arousal and excitement emotions are often displayed by those attending sporting events and, as per Wakefield and Blodgett (1994), we thus frame attendance as engaging in a 'sporting experience'. Fans experience joy, anger, suspense or contentment as they watch the game unfold (Westerbeek \& Shilbury, 2003), which has implications for overall satisfaction. Research investigating the attributes of service quality across a range of sectors has examined the relationship between customer satisfaction and behavioural intentions. Key findings show how the perception of high quality service has a significant influence on customer satisfaction 
and revisit intention (Zeithaml, Bitner \& Gremler, 2006; Kim, Ko \& Park, 2013). As the attraction and retention of new and existing spectators is essential to the financial viability of sport stadia, we expect quality to be high on the agenda for the sports operations manager.

Research has identified specific service attributes to frame spectators' perceptions of service quality at sporting events. These attributes include tangibles, responsiveness, security, access, reliability (Theodorakis \& Kambitsis, 1998), employees, price, facility access, concessions, fan comfort, game experience, show time, convenience and smoking (Kelly \& Turley, 2001). More recent research has identified four over-arching attributes used by spectators to evaluate the sporting experience; game performance, in-game entertainment, staff quality and physical surroundings (Ko, Zhang, Cattani \& Pastore, 2011). With reference to these four attributes, game performance is uncertain and the main reason for spectators attending sporting events. This backdrop of uncertainty makes quality management in the sporting event context a particularly interesting focus for further examination. We concentrate on quality attributes that can and cannot be controlled. Building on research that examines spectator satisfaction at sporting events, we focus on the management of operations that take place off-field. Unlike on-field performance, off-field operations can be controlled. They are thus critical in co-ordinating and managing resources to meet spectator expectations whilst ensuring cost-effective service delivery (Trenberth, 2012; Rodrigues, Valdunciel \& MiguelDavila, 2014).

On-field uncertainty poses management challenges for the perception of services delivered off-field. The challenge is further exacerbated by the experiential nature of both uncertainty and quality, and hence there is a question as to whether a negative on-field outcome necessarily results in a disappointing overall spectator experience. Furthermore, in addition to their team winning, there are many things that the spectators at sport stadia want to see that are difficult for managers to incorporate (Greenwell, Danzey-Bussell \& Shonk, 2014). For 
example, stress free selection of seats and low booking charges; ample information as regards getting to the venue; seamless transport and access to and around the venue; not too long a walk from transport to seat; an unobstructed seating position; easy access to bathroom facilities and food vendors; value adding use of mobile technology (tickets; admission; upgrades; as a screen on which to view slow motion reruns; informing which is the shortest restroom/food vendor queue, making an 'in process' complaint to allow correction/intervention by the venue team, etc) (Getz \& Page, 2016; Parent \& Chappelet, 2015; Parent \& Smith-Swan, 2013). As per Abdullah \& Rozario (2009) our premise is that sport operations managers will be focused on understanding spectator requirements (expectation) and developing associated processes (process quality) to deliver these requirements (output quality).

We suggest that off-field quality management is essential to this multi-million dollar business and also recognize that whilst the literature is replete with examples of quality management in numerous industrial settings, the application of quality management to the sporting industry is often overlooked (Machuca, Gonzalez-Zamora \& Aguilar-Escobar, 2007). Studies in this area have largely focused on quality in terms of athletic performance and thus limited attention has been paid to managing the essential operations taking place off-field. In such a hedonic service and leisure setting as sports stadia, consumers evaluate the entire service experience (Hightower, Brady \& Baker, 2002). Yet the key outcome, the result of the athletic competition, is outside management's control. With a growing interest in the financial gains to be achieved from the 'servicescape' of sporting venues (Hightower et al., 2002) we would expect to see a focus on the use of quality management practices off-field in an attempt to regulate the aspects of the sporting experience that can be controlled. For example, variables such as perceived waiting time have been shown to have a negative impact on repeat purchase decisions and yet are within the control of operations managers (Taylor, 1994). We thus anticipate that the continuous improvement of off-field operations is a current priority for sport 
operations managers and use the following research question to frame our study: Does environmental uncertainty impact the orientation of quality management practices in a sporting context?

Our paper is structured as follows: First, we discuss the concepts of quality management and environmental uncertainty with reference to off-field sporting operations and go on to develop hypotheses based on this discussion. We next provide details of the survey method that was employed to gather primary data from sport operations managers in the United Kingdom, United States, Canada, Australia and New Zealand. We then present the survey results and discuss their implications for quality management in the off-field sporting context and finally offer conclusions, acknowledge the study's limitations and offer suggestions for further work.

\section{Quality management and sports operations}

\section{The sports operations context}

We contribute to the quality management literature by focusing on spectator sport. The sporting industry, similar to the leisure industry, shares many of the characteristics typical of services; it is time bound, unable to be stored and is simultaneously produced and consumed (Parasuraman, Zeithaml \& Berry, 1985). The context, however, is somewhat different from many services as the outcome is unpredictable; often the key reason for its popularity (Neale, 1964; Trenberth, 2012). The unpredictable nature of sporting competitions has immediate consequences for the management of off-field operations. For example, a negative on-field outcome can impact the perceived quality of the services provided off-field (e.g. length of queues and customer service) (Kauppi, Moxham \& Bamford, 2013). Sports stadia are reliant upon fans attending events and hence off-field operations must ensure customer satisfaction, particularly given the range of alternative engagement options that are readily available for 
spectators (e.g. television sports channels, public broadcasting of events and online choices), and the almost instantaneous reputational damage that can be delivered through social media channels (Aula, 2010). Falling attendance also negatively impacts the phenomenon of home advantage (whereby the home players are psychologically lifted by the crowd) (Wolfson, Wakelin \& Lewis, 2005). Additionally, the planning of subsequent sporting competitions is often contingent on the outcome of current play and decisions are consequently taken at short notice (Downward, Lumsdon \& Weston, 2009). We therefore conceptualize the sporting context as one of high environmental uncertainty by drawing on Milliken (1987) and Daft (2004) whereby limited information about environmental factors impacts on the ability to predict something accurately.

\section{Spectator co-creation and enforced collaboration as environmental uncertainty}

To situate our study firmly in the sporting context, we draw on spectator co-creation and enforced collaboration as specific forms of environmental uncertainty. In terms of spectator co-creation, experience and perception are seen as essential to value determination (Vargo \& Lusch, 2006) and one of the primary reasons that spectators attend sporting events is to be part of the atmosphere; this can be associated with components of the leisure industry. Fans are thus co-creators of the sporting experience (Basole \& Rouse, 2008; Vargo, Maglio \& Akaka, 2008) and yet often have to pay to attend and therefore have expectations in terms of both onfield and off-field performance. The concept of fans paying to attend and being part of the cocreation of the event is novel and important to recognize. The level of engagement of fans is uncertain, and thus to maintain a high level of service quality sports stadia must identify how to maintain interest, enjoyment and attendance at the events, even when games are not markedly exciting (Clemes, Brush \& Collins, 2011). Sport operations managers need to 
understand the role of customers as partial employees and subsequently how, as co-creators, customers can potentially impact the determination of value.

Across all sports, competitors need to collaborate with their rivals to enable future sporting events to take place (Neale, 1964; Stewart \& Smith, 1999). This enforced collaboration requires co-operation off-field to agree admission fees, revenue distribution, broadcasting and media arrangements (Cairns, Jennett \& Sloane, 1986; Szymanski \& Kuypers, 1999). Rivals must also work together to develop last minute schedules of play that ensure competitive balance (Downward et al., 2009; O'Reilly, Nadeau \& Kaplan, 2011) and are logistically possible (Schwarz, Hall \& Shibli, 2010).

\section{Orientation of quality management practices}

Maintaining a customer and process focus are seen as essential to quality management (Dean \& Bowen, 1994). Customer focus is viewed as a vital constituent of quality management and essential to long term success (Samson \& Terziovski, 1999). It demonstrates an organizational commitment to identifying existing and emerging customer needs, understanding customer expectations and preferences, and developing appropriate measures of satisfaction (Mosadeghrad, 2014).

Process focus is concerned with understanding and improving processes in order to maintain a consistent level of performance (Mosadeghrad, 2014). Designing, controlling and improving processes to meet functional and customer requirements necessitates a focus on the reduction of process variance with the objective of fewer process failures (Flynn, Schroeder \& Sakakabara, 1995). It emphasizes the management of process over outcomes (Anderson, Rungtusanatham \& Schroeder, 1994; Mehra \& Ranganathan, 2008) and is particularly pertinent to the simultaneous production and consumption environment of services (Harvey, 1998; Psomas \& Jaca, 2016). In the off-field sporting context, a process focus may be operationalized 
through the collection of data and the use of statistical techniques to ensure a smooth customer flow during activities, including queuing for tickets, entering and exiting the venue during peak periods and purchasing refreshments during breaks in play.

\section{Development of hypotheses}

In uncertain environments, organizations are encouraged to focus on quality management as a mechanism for improving customer satisfaction (Jabnoun, Khalifah \& Yusuf, 2003). Given the environmental uncertainties of spectator co-creation and enforced collaboration, we would expect quality management practices to be widely utilized in off-field sporting operations to ensure customer satisfaction regardless of the on-field outcome. In sport many factors are outside of the control of managers, including the on-field athletic competition, as well as more operational factors including the co-ordination of competing teams and how spectators act as co-producers both in the operations and in the creation of the atmosphere (Kelley \& Turley, 2001; Stewart \& Smith, 1999). We therefore expect to see a focus on the customer and on the process to manage those aspects of the sporting experience that can be controlled, and thus propose the following hypotheses:

H1: Higher levels of environmental uncertainty in the form of spectator co-creation lead to

a) higher orientation of customer focus for quality management practices.

b) higher orientation of process management for quality management practices.

H2: Higher levels of environmental uncertainty in the form of enforced collaboration lead to

a) higher orientation of customer focus for quality management practices.

b) higher orientation of process management for quality management practices. 
Our full hypothesized model is presented in Figure 1.

[insert Figure 1 here]

\section{Research Methods}

\section{Survey design and constructs}

We collected data through a multi-country survey. Our survey was developed to identify and study the quality management practices that are currently used by sport stadia operations managers in the United Kingdom, United States, Canada, Australia and New Zealand. These target countries were chosen because an English language questionnaire and similar linguistic background reduces possible data equivalence issues in the sample (Choi, Minhee, Scott \& Martin, 2010). In item and construct development, pre-existing scales from operations and quality management literature were used as such, or as slightly modified to fit the stadium context.

The items for quality management practices were adopted from Zhang, Linderman and Schroeder (2012), with slight wording modifications to reflect the service/sport venue context as opposed to their manufacturing setting. Similar to Zhang et al., (2012) both Process management focus for quality management practices and Customer focus for quality management practices were measured with items, where respondents were asked to indicate on a 7-point agree/disagree Likert scale the use of several quality management techniques. The items for Spectator co-creation and Enforced collaboration were derived through a construct development approach, via the q-sorting method (Moore and Benbasat, 1991). Both were also measured on a 7-point agree/disagree scale, with Enforced collaboration containing seven 
items and Spectator co-creation containing seven items. The survey items are present in Appendix A.

\section{Data collection method}

Our unit of analysis was sport stadia and the target respondents were stadium operations managers (or equivalent). Sampling was especially difficult in this context given that no databases of stadia operations managers existed from which to draw a random sample. Additionally, sport stadia and other spectator locations do not have their own ISIC code. We therefore set out to develop a database of sports operations management professionals with the aim of representation (by identifying a proportional amount of contacts in different types of stadia/sports given the popularity of the sport and in the different countries) by using sport club websites. Based on targets in countries and sports leagues, we attempted to identify potential stadia and respondents therein through organizational websites and LinkedIn. Additionally, we used snowball sampling in that respondents were asked to recommend colleagues at other stadia that could be contacted to complete the survey. Overall, our sampling thus represents a convenience approach. Respondents were first sent a pre-notification letter to inform them of the survey, followed by an email and/or paper survey. Ethics procedures at one of the author's institution prevented us from pre-calling the respondents, which may have had an adverse impact on the response rate. Three reminders were sent to increase the response rate.

Following our sustained attempt to identify respondents, the survey was then sent in total to 579 managers. 71 responses were received (each representing an individual sport stadium), giving a $12 \%$ response rate, which is in the similar range of other operations management empirical studies (Dabhilkar, Bengtsson \& Lakemond, 2016; Tachizawa, Gimenez \& Sierra, 2015; van der Vaart, van Donk, Gimenez \& Sierra, 2012). Receiving a high volume of responses proved particularly difficult in this novel setting, as per other studies 
published in the sport literature: for instance, Mallen, Adams, Stevens and Thompson (2010) relied on a total of 31 expert participants and reported quantitative results; Mallen, Stevens, Adams and McRoberts (2010) reported their questionnaire result 'based on a very small sample' of 15 event managers and Girginov, Papadimitriou and López De D'Amico (2006) also surveyed 15 sport managers from 7 countries to construct their results. Many empirical studies within sport management have taken place either with the consumers (e.g. the fans) or have adopted a more marketing approach (e.g. businesses). It appears that our target respondents were not used to being asked to take part in academic research. It also became evident as we were contacting the respondents that many of those targeted were not the correct key informants in the organization due to the different use of the term "operations manager" within the sport industry (it often refers to a role more related to the actual on-field sport operations). It is therefore likely that our actual representative sample was much lower than the 579 quoted above (which would lead to a higher response rate than the $12 \%$ reported). Green, Inman, Birou and Whitten (2014) note that although higher response rates are desired, in industrial research low response rates can often occur when complex survey instruments are used and response rates between 3\% and 10\% have appeared in management research publications (Dabhilkar et al., 2016; Leyer \& Moormann, 2014; Kristal, Huang \& Roth, 2010). In total, our 12\% response rate across the survey is broken down as $15.2 \%$ for the UK, $3.3 \%$ for the US, $10.6 \%$ for Canada and $14 \%$ for Australia and New Zealand. Klassen and Jacobs (2001) actually suggest item completion rate as an alternative measure for assessing survey effectiveness. We calculated our item completion rate in the returned surveys to be $97 \%$, equal to that of Green et al., (2014), and thus an indicator of the respondents having been comfortable with the meanings of the survey items.

\section{Descriptive statistics}


In Table 1, the distribution of responses based on venue characteristics and country is presented, while Table 2 shows the characteristics of the respondents (the venue operations managers). The venue types presented a variety of venues within the industry (and are thus likely to demonstrate variation in the levels of uncertainty present at each venue), and from Table 2 it can be seen that our respondents are knowledgeable of the topic given their typically extensive work experience within the industry.

[insert Table 1 here]

[insert Table 2 here]

The descriptive statistics for the core constructs are presented in Appendix B. The construct scores are calculated as means of the standardized item scores.

\section{Bias testing}

In the design of the survey several attempts were made to avoid common method bias; questions on strategies, practices and performance were placed at different sections in the questionnaire (proximal separation) (Podsakoff, MacKenzie \& Podsakoff, 2003), and the sequence of items was randomized for the online version (Chang, van Witteloostuijn \& Eden 2010). Furthermore, in line with suggestions by Lindell and Whitney (2001), we included marker variables in the survey to allow for common method bias testing. Specifically, the two marker variables, expected to be theoretically uncorrelated with our survey items, were "I regularly use social media for work purposes" and "I regularly receive useful information from the national governing body for the main sport at our venue”. A correlation between a marker variable and other variables in the survey would indicate existence of common method 
bias (Kauppi \& van Raaij, 2015). The marker variables were not (systematically nor significantly) correlated to the other variables in our survey. Furthermore, we used the Harman's single factor test (Chang et al., 2010) to test for potential common method bias by loading all the items used in our testing into an exploratory factor analysis. Several factors emerged as expected, and the first factor only represented $25 \%$ of the variance in the data. Based on these two analyses, we can conclude that common method bias is not present within the data.

\section{Reliability and validity}

To estimate construct reliability and validity, we conducted a confirmatory factor analysis with SPSS AMOS v.23. During confirmatory factor analysis, several items from Spectator cocreation and Enforced collaboration (items SC3, SC5 and SC7 as well as items EC3 and EC7) were eliminated due to low factor loading on their respective constructs. Similarly, one item from Process management focus for quality management (PQM2) was also removed. The final set of items for each construct, along with standardized factor loadings and corresponding t-

values are presented in Table 3. In this table, the results for construct convergent and discriminant validity are also provided. Specifically, as the estimated coefficients for all items are significant $(\mathrm{t}>2)$ this indicates convergent validity. Furthermore, as the average variance extracted (AVE) for all constructs apart from Spectator co-creation meets or exceeds the minimum value of 0.5 and the composite reliability $(\mathrm{CR})$ values all exceed those of 0.7 (Hair, Black, Babin, Anderson \& Tatham, 2005), we can confirm convergent and discriminant validity. Additionally, we used Cronbach's alpha for construct validity estimation, these are also presented in Table 3, and all exceed the minimum level of 0.70 expected (Nunnally, 1978). While Spectator co-creation just falls below the recommended minimum AVE value, with a 
value of 0.49 , we have deemed this acceptable given all the other indicators are at acceptable levels, and the construct is newly developed.

[insert Table 3 here]

To estimate model fit, several absolute ( $\chi^{2}$ test, the normed $\chi^{2}$, and the root meansquare error of approximation i.e. RMSEA) as well as incremental measures (the comparative fit index i.e. CFI and the Tucker-Lewis index i.e. TLI) were used. The $\chi^{2}$ value for the final model after item deletions is 80.23 , with 71 degrees of freedom. The normed $\chi^{2}$ corrects the $\chi^{2}$ for model size (Shah \& Goldstein, 2006), where values between 1.0 and 3.0 are seen to indicate model fit (Jöreskog, 1969). For our model, the value is 1.13, fulfilling this criterion. Our RMSEA of 0.043 also fulfils the cut-off point of below 0.06 , while both CFI 0.974 and TLI 0.966 exceed the minimums of 0.95 (Hu \& Bentler, 1999). Overall, the model thus demonstrates good fit to the data.

\section{Results}

We built two regression models, one for each dependent variable, i.e. customer focus and process focus for quality management practices, using linear regression analysis with SPSS Statistics v.23. The results are presented in Table 4.

[insert Table 4 here]

Only H1b regarding the relationship between Spectator co-creation and use of Process management holds, i.e. higher levels of this type of environmental uncertainty lead to higher use of quality management techniques in venue operations. Surprisingly, for Enforced 
collaboration and Process management, a result opposite to that expected and hypothesized is found (though this is only significant at $\mathrm{p}=0.067$ ). The higher the experienced Enforced collaboration, the less likely the organization is to use quality management practices in their operations. Regarding Customer focus for quality management, neither H1a nor H2a hold, i.e. we find no significant relationship between the environmental uncertainty constructs tested and the use of quality management practices.

\section{Discussion}

We tested the impact of two contextual uncertainty factors in the sporting industry, spectator co-creation and enforced collaboration, on the orientation of customer focused and/or process focused quality management practices. The intention was to explore the link between uncertainty and quality management practices. While both types of environmental uncertainty result in a process management focus (although this is only a marginally significant result with regards to enforced collaboration), surprisingly neither has an impact on the utilization of customer focused quality management practices. A process focus for venue and stadium operations is to be expected, particularly in large venues with thousands of spectators, and concerns the reduction of process variance (Dean \& Bowen, 1994; Flynn et al., 1995). Process oriented quality management practices are used to facilitate a smooth entry and exit to the venue for spectators so that fans can arrive to the game on time and leave in a safe and orderly fashion. Furthermore, such practices ensure appropriate seating arrangements for home and visiting fans, permit refreshments to be served in a timely manner during breaks and ensure that the scheduling of events and the associated media requirements run to time (Wolfson, Wakelin \& Lewis, 2005; Downward et al., 2009; O'Reilly, Nadeau \& Kaplan, 2011; Schwarz, Hall \& Shibli, 2010). 
The lack of customer orientation as regards quality management practices in an uncertain environment is surprising, particularly as customer satisfaction is often seen as important to the success of sporting events (Bamford \& Dehe, 2016; Kelley \& Turley, 2001). In consequence, and as per the research on strategic focus by Reed, Lemak and Montgomery (1996), this finding would suggest that sport event providers have a focus on the operations rather than the customer as a means of enhancing financial performance. One reason for this may be the traditionally held view that spectators are essentially consumers rather than cocreators of the sporting product; a view challenged by Woratschek, Horbel and Popp (2014) in the development of their sport value framework. Service and leisure industries research has an inherent focus on process (Parasuraman et al., 1985), which has more recently been augmented by research examining the co-creation of value through interactivity (McColl-Kennedy, Vargo, Dagger, Sweeney \& van Kasteren, 2012). Such research would suggest that sport spectators are active in the co-creation of value by engaging with the sporting experience (Bendapudi \& Leone, 2003; Woratschek et al., 2014). Orienting quality management practices towards the customer, particularly in the context of spectator co-creation, would require a focus on value. However, recent research has acknowledged a dearth of analysis on value co-creation among team sport customers (Uhrich, 2014). In line with the lack of scholarly work on the topic, sport operations managers appear to be unclear or uninterested in orienting quality management practices towards customer co-creation of value, perhaps assuming that loyal customers (i.e. the fans) will continue to consistently attend.

A further reason for the lack of customer orientation may be the market position traditionally held by sport stadia. Until relatively recently, sports fans had the option of attending the live event at the stadium or, if available, watching the event broadcast on television. For many sports fans the atmosphere of the live event is always preferable (Uhrich \& Benkenstein, 2010). Hence, sport stadia have traditionally been the only option available 
for those wishing to experience the atmosphere of the sporting event. More recently, however, a number of additional means of viewing and engaging in sporting events have become available. Examples include live streaming of events via the Internet, licences held by alternative venues to show live sport, and dedicated sport television channels. Social media may also be used to enhance the sporting experience, connecting those attending the event with those watching elsewhere and/or allowing online spectator communities to interact in a manner that was previously only open to those attending in person (Mahan \& McDaniel, 2006). Alternative means of engaging in the sporting experience may go some way to explaining the drop-off in attendance at live games (Koba, 2013). Our findings suggest a lack of awareness of the importance of maintaining a customer focus in a market that has recently become much more competitive, and which continues to evolve at a rapid rate.

As Sitkin, Sutcliffe and Schroeder (1994) point out, quality management includes both control as well as a more customer oriented learning approach, and managers often cannot settle for one or the other in blissful isolation. To illustrate the importance of simultaneously considering the process and the customer, Bamford and Dehe (2013) identify two key elements of fan and customer satisfaction in a UK sports club: i) Operations service quality as a strategic weapon; and ii) positioning the experience to meet the needs of the sport consumer. These findings concur with Clemes et al., (2011) who conclude that for sports clubs to succeed, they have to strategically manage spectator perceptions of service quality and understand how these perceptions affect value, satisfaction and behaviour. The management of perceptions is particularly challenging in the sporting environment as agreement as to the exact nature of customer satisfaction has yet to be reached (van Leeuwen, Quick \& Daniel, 2002). Scholars encourage the measurement of customer satisfaction; the results of which should be used to shape the operations of the servicescape accordingly (Kelley \& Turley, 2001). In this context it appears that the expectations of the sporting consumer could be used to develop appropriate 
measures and approaches to managing processes. It therefore follows that a skewed focus towards process may neglect input from the customer, and be to the detriment of the continuous improvement of the sporting experience.

Literature examining the contingencies of quality management is in short supply, particularly with regards to the service sector (Zhao, Yeung \& Lee, 2004). For spectator sport we found that high environmental uncertainty, in terms of spectator co-creation, lead to a greater orientation of process focused quality management practices, however high environmental uncertainty, in terms of enforced collaboration, lead to a reduced orientation of process focused quality management practices. This is in contrast to scholars who have encouraged a focus on the customer when environmental uncertainty is high (Jabnoun et al., 2003). A focus on the process is typical in manufacturing (Samson \& Terziovski, 1999) and hence we found this predominant orientation to be unexpected given that the context is anything but a traditional manufacturing environment. Studies anticipate that service organizations will focus more on the customer than the process given the high customer contact (Reed et al., 1996), yet this was not borne out in our findings.

Context is important to studies on quality management (Reed et al., 1996; Sitkin et al., 1994). Consequently, in considering context it may be unhelpful to generalize and consider every sporting experience as homogenous. Our findings, however, do show a skewing of quality management towards 'process' across a variety of sports, stadia and countries. This suggests a link between process management practice orientation and environmental uncertainty in a number of different sporting settings. As alluded to earlier, we suggest that the findings may go some way to explaining the decrease in attendance at stadia sporting events (Koba, 2013; Buraimo, Forrest \& Simmons, 2008; Gilmour, 2010) due to a reduced focus on the person as compared with the process. Scholars highlight how limited attention has been devoted to the study of the innovation of sport event experiences (Yoshida, James \& Cronin, 
2013) and thus aspects of quality management as applied to the sports venue servicescape appear largely underrepresented.

\section{Conclusions and Further Work}

Managerially, our interpretation of the results and the reviewed literature (Ko \& Pastore, 2007; Parent \& Chappelet, 2015; Theodorakis \& Kambitsis, 1998) lead us to suggest that whilst sporting stadia are currently orientated towards process management in an effort to temper environmental uncertainty, equal attention should be paid to customer co-creation of value. With many alternative channels through which fans can enjoy sporting events, and with an increased offering of alternative service experiences overall, simply being efficient at managing processes may be insufficient to remain financially viable. Sport industry operations managers are encouraged to put more of a focus on understanding customer needs given that previous research has shown how customer satisfaction and service quality perceptions impact repeat attendance (Hall, O’Mahony \& Vieceli, 2010; Hill \& Green, 2000; Theodorakis et al., 2009). It could be argued that the link between uncertainty and quality is somewhat difficult to delineate; both being essentially experiential, especially within the service, sport and leisure industries. Perhaps, therefore, our results show the "baseline benchmark" for the industry. That those exhibiting an orientation towards process management are more advanced, as many stadia may not yet implement any aspect of quality management. We suggest that even a slight move in the direction of more defined operational control could benefit the spectator experience; whilst still acknowledging that many elements are outside the scope of influence of the venue team.

Our sample size posed some limitations to the amount of variables that could be included in the study, as well as to the implications of the findings, which are tentatively made (c.f.: Dabhilkar et al., 2016; Mallen et al., 2010). As discussed, we found it difficult to establish 
and reach the sample in this novel and "less central" industry. Nevertheless, we urge researchers to continue to explore this field, as future research with larger samples could accommodate more advanced structural equation models in which performance variables can also be included. This would be important in developing a contingency theory of quality management in various service contexts, including sport, as it is important to identify fit and misfit between practices, contexts, and the ensuing performance (Sila, 2007). The effectiveness of a service quality management system may be contingent on its operating environment; therefore we hope our research encourages more contingency theory oriented viewpoints as to what works in the sport industry and more broadly in the service and leisure industry.

The distinctive environmental uncertainty features of enforced collaboration and spectator co-creation appear in a variety of sport management research, yet we are not aware of attempts to systematically define these special characteristics and develop measures for them for survey studies. The operationalization of these constructs through measures with high degrees of validity and reliability is essential to establishing a cumulative and systematic body of work and advancing theory development and testing (Froehle \& Roth, 2004; Moore \& Benbasat, 1991). A review of survey studies in the three key sport management journals European Sport Management Quarterly, Sport Management Review and Journal of Sport Management - demonstrates that only a handful of studies (e.g. Chen, 2004; Clemes et al., 2011; Kim \& Walker, 2012; Shapiro, Giannoulakis, Drayer \& Wang, 2010; and Yoshida et al., 2013) describe procedures as found in q-sorting in item development, before survey testing. Our development approach is thus relevant and called for. We do, however, recognize the limited sample size in hindering the validation of the new scales, and urge other researchers to further test and use them in other survey settings.

As a multinational survey, our data could be subject to data inequivalence, i.e. elements of the research might be understood or applied differently across cultural contexts. Given that 
all the countries in our sample are English-speaking, and that equivalence issues are more typical in cross-cultural studies between American and Asian samples (i.e. cultures with large differences) rather than Western countries (Karjalainen and Salmi, 2013), we believe differences in how the respondents perceived the questions should be minimal. While data equivalence can be analysed post-data collection, our limited sample size and associated response rate (especially for the US) prevented it in this research. We thus urge more studies to test the constructs further in the US, and the results across different countries and/or cultural contexts.

We would also encourage further work to examine the application of teamwork in conjunction with a process and a customer focus to provide further evidence of the application of quality management to the off-field sporting context. This is important as operations management research generally has been reluctant to venture into leisure industries such as tourism, culture and sport, as already indicated by Machuca et al. (2007). This is despite an increasing interest from consumers in purchasing experiences, and not just products (Bigné, Mattila \& Andreu, 2008). We acknowledge that we have merely scratched the surface of an exciting and complex context with our study, and thus use this opportunity to relaunch the call by Machuca et al., (2007) for a specific focus on more quality management research into the economically and socially important leisure industry, particularly in terms of customer cocreation of value.

\section{References}

Abdullah, D. \& Rozario, F. (2009). Influence of service and product quality towards customer satisfaction: A case study at the staff cafeteria in the hotel industry. World Academy of Science, Engineering and Technology, 53, 346-351. Retrieved from: http://waset.org/publications/15478/influence-of-service-and-product-qualitytowards-customer-satisfaction-a-case-study-at-the-staff-cafeteria-in-the-hotel-industry 
Anderson, J., Rungtusanatham, M. \& Schroeder, R. (1994). A theory of quality management underling the Deming management method. Academy of Management Review, 19, 472509. doi:10.5465/AMR.1994.9412271808

Aula, P. (2010). Social media, reputational risk and ambient publicity management. Strategy and Leadership, 38, 43-49. doi: 10.1108/10878571011088069

Bamford, D. \& Dehe, B. (2013, June). Servicescape in sports: Levels of fan satisfaction in a UK Rugby League Club. Paper presented at the European Operations Management Association (EurOMA) Conference, Dublin, Ireland.

Bamford, D. \& Dehe, B. (2016). Service quality and the London 2012 Games - a Paralympics athletes survey. International Journal of Quality and Reliability Management, 33, 142159. doi: 10.1108/IJQRM-05-2014-0058

Basole, R.C. \& Rouse, W.B. (2008). Complexity of service value networks: conceptualization and empirical investigation. IBM Systems Journal, 47, 53-70. doi: 10.1147/sj.471.0053

Bendapudi, N. \& Leone, R. (2003). Psychological implications of customer participation in coproduction. Journal of Marketing, 67, 14-28. doi: 10.1509/jmkg.67.1.14.18592

Bigné, J.E., Mattila, A.S. \& Andreu, L. (2008). The impact of experiential consumption cognitions and emotions on behavioral intentions. Journal of Services Marketing, 22, 303-315. doi: 10.1108/08876040810881704

Buraimo, B., Forrest, D. \& Simmons, R. (2009). Insights for clubs from modelling match attendance in football. Journal of the Operational Research Society, 60, 147-155. doi: 10.1057/palgrave.jors.2602549.

Cairns, J., Jennett., N. \& Sloane, P. (1986). The economics of professional team sports: A survey of theory and evidence. Journal of Economic Studies, 13, 3-80. doi: $10.1108 / \mathrm{eb} 002618$ 
Chang, S.-J., van Witteloostuijn, A. \& Eden, L. (2010). From the editors: Common method variance in international business research. Journal of International Business Studies, 4, 178-184. doi:10.1057/jibs.2009.88

Chen, L. (2004). Membership incentives: Factors affecting individual's decisions about participation in athletics-related professional associations. Journal of Sport Management, 18, 111-131. doi.org/10.1123/jsm.18.2.111

Choi, Y., Minhee, S., Scott, D. \& Martin, J. (2010). Validation of the organizational culture assessment instrument: An application of the Korean version. Journal of Sport Management, 24(2), 169-189. doi: 10.1123/jsm.24.2.169

Clemes, M., Brush, G. \& Collins, M. (2011). Analysing the professional sport experience: A hierarchical approach. Sport Management Review, 14, 370-388. doi: 10.1016/j.smr.2010.12.004

Dabhilkar, M., Bengtsson, L., \& Lakemond, N. (2016). Sustainable supply management as a purchasing capability: A power and dependence perspective. International Journal of Operations and Production Management, 36, 2-22. doi: 10.1108/IJOPM-12-2014-0609

Daft, R.L. (2004). Organizational theory and design. Cincinnati: South Western College Publishing.

Dean, J.W. \& Bowen, D.E. (1994). Management theory and total quality: Improving research and practice through theory development. Academy of Management Review, 19, 392418. doi: 10.5465/AMR.1994.9412271803

Downward, P., Lumsdon, L. \& Weston, R. (2009). Visitor expenditure: The case of cycle recreation and tourism. Journal of Sport and Tourism, 14, 25-42. doi: $10.1080 / 14775080902847397$ 
Flynn, B., Schroeder, R. \& Sakakabara, S. (1995). The impact of quality management practices on performance and competitive advantage. Decision Sciences, 26, 659-692. doi: 10.1111/j.1540-5915.1995.tb01445.x

Froehle, C. M. \& Roth, A. V. (2004). New measurement scales for evaluating perceptions of the technology-mediated customer service experience. Journal of Operations Management, 22, 1-21. doi: 10.1016/j.jom.2003.12.004

Getz, D. \& Page, S.G. (2016). Event Studies: Theory, Research and Policy for Planned Events. $3^{\text {rd }}$ edition, Oxford: Taylor and Francis eBooks. doi: 10.4324/9781315708027

Girginov, V., Papadimitriou, D. \& López De D'Amico, R. (2006). Cultural orientations of sport managers. European sport management quarterly, 6, 35-66. doi: $10.1080 / 16184740600798347$

Gilmour, R. (2010) Commonwealth Games 2010: What's going wrong in Delhi today?, The Telegraph, 13th October

Green, K., Inman, R., Birou, L. \& Whitten, W. (2014). Total JIT (T-JIT) and its impact on supply chain competency and organizational performance. International Journal of Production Economics, 147, 125-135. doi: 10.1016/j.ijpe.2013.08.026

Greenwell, T.G., Danzey-Bussell, L.A. \& Shonk, D. (2014). Managing Sport Events. Champaign, IL: Human Kinetics

Hair, J., Black, W., Babin, B., Anderson, R. \& Tatham, R. (2005). Multivariate Data Analysis. New Jersey: Prentice-Hall.

Hall, J., O'Mahony, B. \& Vieceli, J. (2010). An empirical model of attendance factors at major sporting events. International Journal of Hospitality Management, 29, 328-334. doi: 0.1016/j.ijhm.2009.10.011

Harvey, J. (1998). Service quality: A tutorial. Journal of Operations Management, 16, 583597. doi: 10.1016/S0272-6963(97)00026-0 
Hightower, R., Brady, M. \& Baker, T. (2002) Investigating the role of the physical environment in hedonic service consumption: An exploratory study of sporting events. Journal of Business Research, 55, 697-707. doi: 10.1016/S0148-2963(00)00211-3

Hill, B. \& Green, B. (2000). Repeat attendance as a function of involvement, loyalty, and the sportscape across three sport contexts. Sport Management Review, 3, 145-162. doi: $10.1016 / \mathrm{S} 1441-3523(00) 70083-0$

Hu, L. \& Bentler, P. (1999). Cutoff criteria for fit indexes in covariance structure analysis: Conventional criteria versus new alternatives. Structural Equation Modeling: A Multidisciplinary Journal, 6, 1-55. doi: 10.1080/10705519909540118

Jabnoun, N., Khalifah, A. \& Yusuf, A. (2003). Environmental uncertainty, strategic orientation, and quality management: A contingency model. The Quality Management Journal, 10, 17-31. Retrieved from http://search.proquest.com/openview/1c8e476294eda1cc91bb2d5db1e9157a/1?pqorigsite $=$ gscholar $\& \mathrm{cbl}=31933$

Jöreskog, K. (1969). A general approach to confirmatory maximum likelihood factor analysis. Psychometrika, 34, 183-202. doi: 10.1002/j.2333-8504.1967.tb00991.x

Karjalainen, K. \& Salmi, A. (2013). Continental differences in purchasing strategies and tools. International Business Review, 22, 112-125. doi: 10.1016/j.ibusrev.2012.02.008

Kauppi, K., Moxham, C. \& Bamford, D. (2013). Should we try out for the major leagues? A call for research in sport operations management. International Journal of Operations and Production Management, 33, 1368-1399. doi:10.1108/IJOPM-11-2011-0418

Kauppi, K. \& van Raaij, E., (2015). Opportunism and honest incompetence - seeking explanations for noncompliance in public procurement. Journal of Public Administration: Research and Theory, 25, 953-979. doi: 10.1093/jopart/mut081 
Kelley, S. \& Turley, L. (2001). Consumer perceptions of service quality attributes at sporting events, Journal of Business Research. 54, 161-166. doi: 10.1016/S01482963(99)00084-3

Kim, T., Ko, Y. J. \& Park, C. (2013). The influence of event quality on revisit intention: Gender difference and segmentation strategy. Managing Service Quality, 23, 205-224. doi: $10.1108 / 09604521311312237$

Kim, W. \& Walker, M. (2012). Measuring the social impacts associated with Super Bowl XLIII: Preliminary development of a psychic income scale. Sport Management Review, 15, 91-108. doi:10.1016/j.smr.2011.05.007.

Klassen, R. \& Jacobs, J. (2001). Experimental comparison of web, electronic and mail survey technologies in operations management. Journal of Operations Management, 19, 713728. doi: $10.1016 / \mathrm{S} 0272-6963(01) 00071-7$

Ko, Y. J., Zhang, J., Cattani, K. \& Pastore, D. (2011). Assessment of event quality of major spectator sports. Managing Service Quality, 21, 304-322. doi: $10.1108 / 09604521111127983$

Ko, Y. J. \& Pastore, D. (2007). An instrument to assess customer perceptions of service quality and satisfaction in campus recreation programs. Recreational Sports Journal, 31, 3442. doi: $10.1123 /$ rsj.31.1.34

Koba, M. (2013). Keeping fans in the stands is getting harder to do. Sports Business, Retrieved from: http://www.cnbc.com/id/100886843.

Kristal, M. M., Huang, X. \& Roth, A. V. (2010). The effect of an ambidextrous supply chain strategy on combinative competitive capabilities and business performance. Journal of Operations Management, 28, 415-429. doi: 10.1016/j.jom.2009.12.002 
Leyer, M. \& Moormann, J. (2014). How lean are financial service companies really? Empirical evidence from a large scale study in Germany. International Journal of Operations and Production Management, 34, 1366-1388. doi: 10.1108/IJOPM-06-2013-0296

Lindell, M. \& Whitney, D. (2001). Accounting for common method variance in cross-sectional research designs. Journal of Applied Psychology, 86, 114-121. doi: 10.1037/00219010.86 .1 .114

Machuca, J., Gonzalez-Zamora, M. \& Aguilar-Escobar, V. (2007). Service operations management research. Journal of Operations Management, 25, 585-603. doi: 10.1016/j.jom.2006.04.005

Mahan, J.E. \& McDaniel, S.R. (2006). The new online arena: Sport, marketing, and media coverage in cyberspace. In A.A. Raney and J. Bryant (Eds), Handbook of Sports and Media, (pp. 409-431), New Jersey: Lawrence Erlbaum.

Mallen, C., Adams, L., Stevens, J., \& Thompson, L. (2010). Environmental sustainability in sport facility management: A Delphi study. European Sport Management Quarterly, 10, 367-389. doi: 10.1080/16184741003774521

Mallen, C., Stevens, J., Adams, L, \& McRoberts, S. (2010). The assessment of the environmental performance of an international multi-sport event. European Sport Management Quarterly, 10, 97-122. doi: 10.1080/16184740903460488

McColl-Kennedy, J., Vargo, S.L., Dagger, T., Sweeney, J. \& van Kasteren, J. (2012). Health care customer value cocreation practice styles. Journal of Service Research, 15, 370389. doi: $10.1177 / 1094670512442806$

Mehra, S. \& Ranganathan, S. (2008). Implementing total quality management with a focus on enhancing customer satisfaction. International Journal of Quality and Reliability Management, 25, 913-927. doi: 10.1108/02656710810908070 
Milliken, F. (1987). Three types of perceived uncertainty about the environment: State, effect and response uncertainty. Academy of Management Review, 12, 133-143. doi: 10.5465/AMR.1987.4306502

Moore, G. C. \& Benbasat, I. (1991). Development of an instrument to measure the perceptions of adopting an information technology innovation. Information Systems Review, 2, $192-$ 222. doi: $10.1287 /$ isre.2.3.192

Mosadeghrad, A. (2014). Essentials of total quality management: A meta-analysis. International Journal of Healthcare Quality Assurance, 27, 544-558. doi: 10.1108/IJHCQA-07-2013-0082

Neale, W. (1964). The peculiar economics of professional sports: A contribution to the theory of the firm in sporting competition and in market competition. The Quarterly Journal of Economics, LXXVIII, 1-14. doi: 10.2307/1880543

Nunnally, C. (1978). Psychometric Theory, New York: McGraw-Hill.

O'Reilly, N., Nadeau, J. \& Kaplan, A. (2011). Do fans want their team to be competitive in the short-term (the next game) or the long term (the full season), and does the answer affect management decisions? European Sport Management Quarterly, 11, 73-86. doi: $10.1080 / 16184742.2010 .537365$

Parasuraman, A., Zeithaml, V.A. \& Berry, L.L. (1985). A conceptual model of service quality and its implications for future research. Journal of Marketing, 49, 41-50. doi: $10.2307 / 1251430$

Parent, M.M. \& Chappelet, J.L. (2015 ). Routledge Handbook of Sports Event Management. Oxford: Routledge. doi: 10.4324/9780203798386

Parent, M.M. \& Smith-Swan, S. (2013). Managing Major Sports Events: Theory and Practice. Oxford: Routledge. doi: 10.4324/9780203132371 
Podsakoff, P., MacKenzie, J.-Y. \& Podsakoff, N. (2003). Common method biases in behavioural research: A critical review of the literature and recommended rememdies. Journal of Applied Psychology, 88, 879-903. doi: 10.1037/0021-9010.88.5.879

Psomas, E. \& Jaca, C. (2016). The impact of total quality management on service company performance: Evidence from Spain. International Journal of Quality and Reliability Management, 33, 380-398. doi: 10.1108/IJQRM-07-2014-0090

PWC. (2016). Sports outlook: At the gate and beyond. Outlook for the sports market in North America through 2020. Retrieved from: https://www.pwc.com/us/en/industry/entertainment-media/publications/assets/pwcsports-outlook-north-america-2015.pdf

Reed, R., Lemak, D. \& Montgomery, J. (1996). Beyond process: TQM content and firm performance. Academy of Management Review, 21, 173-202. doi: 10.5465/AMR.1996.9602161569

Rodrigues, P., Valdunciel, L. \& Miguel-Davila, J. (2014). Quality management in sports tourism. European Sport Management Quarterly, 14, 345-374. doi: $10.1080 / 16184742.2014 .926959$

Sainam, P., Balasubramanian, S. \& Bayus, B. (2010). Consumer options: Theory and an empirical application to a sport market. Journal of Marketing Research, 47, 401-414. doi: $10.1509 / j m k r .47 .3 .401$

Samson, D. \& Terziovski, M. (1999). The relationship between total quality management practices and operational performance. Journal of Operations Management, 17, 393409. doi: 10.1016/S0272-6963(98)00046-1

Schwarz, E.C., Hall, S.A. \& Shibli, S. (2010). Sport Facility Operations Management: A Global Perspective. London: Butterworth-Heinemann,. 
Shah, R. \& Goldstein, S. (2006). Use of structural equation modeling in operations management research: Looking back and forward. Journal of Operations Management, 24, 148-169. doi: 10.1016/j.jom.2005.05.001

Shapiro, S.L., Giannoulakis, G., Drayer, J., \& Wang, C-H. (2010). An examination of athletic alumni giving behavior: Development of the former student-athlete donor constraint scale. Sport Management Review, 13, 283-295. doi: 10.1016/j.smr.2009.12.001.

Sila, I. (2007). Examining the effects of contextual factors on TQM and performance through the lens of organizational theories: An empirical study. Journal of Operations Management, 25, 83-109. doi: 10.1016/j.jom.2006.02.003

Sitkin, S.B., Sutcliffe, K.M. \& Schroeder, R. (1994). Distinguishing control from learning in total quality management: A contingency perspective. Academy of Management Review, 19, 537-566. doi: 10.5465/AMR.1994.9412271813

Smith, A. \& Stewart, B. (2010). The special features of sport: A critical revisit. Sport Management Review, 13, 1-13. doi: 10.1016/j.smr.2009.07.002

Stewart, B. \& Smith, A. (1999). The special features of sport. Annals of Leisure Research, 2, 87-99. doi: 10.1080/11745398.1999.10600874

Szymanski, S. \& Kuypers, T. (1999). Winners and Losers: The Business Strategy of Football. London: Viking Press.

Tachizawa, E. M., Gimenez, C. \& Sierra, V. (2015). Green supply chain management approaches: drivers and performance implications. International Journal of Operations and Production Management, 35, 1546-1566. doi: 10.1108/IJOPM-01-2015-0023

Taylor, S. (1994). Waiting for service: The relationship between delays and evaluations of service. Journal of Marketing, 58, 56-69. doi: 10.2307/1252269

Theodorakis, N., Koustelios, A., Robinson, L. \& Barlas, A. (2009). Moderating the role of team identification on the relationship between service quality and repurchase intentions 
among spectators of professional sports. Managing Service Quality, 19, 456-473. doi: $10.1108 / 09604520910971557$

Theodorakis, N. \& Kambitsis, C. (1998). The effect of service quality on sport consumers' behavioural intentions. Proceedings of the $6^{\text {th }}$ Congress of the European Association for Sport Management, Maderia

Trenberth, L. (2012). The sport business industry. In L. Trenberth and D. Hassan (Eds), Managing Sport Business: An Introduction, London: Routledge.

Uhrich, S. (2014). Exploring customer-to-customer value co-creation platforms and practices in team sports. European Sport Management Quarterly, 14, 25-49. doi: $10.1080 / 16184742.2013 .865248$

Uhrich, S. \& Benkenstein, M. (2010). Sport stadium atmosphere: Formative and reflective indicators for operationalizing the construct. Journal of Sport Management, 24, 211237. doi: $10.1080 / 16184742.2013 .865248$

van der Vaart, T., Pieter van Donk, D., Gimenez, C. \& Sierra, V. (2012). Modelling the integration-performance relationship: Collaborative practices, enablers and contextual factors. International Journal of Operations and Production Management, 32, 1043 1074. doi: $10.1108 / 01443571211265693$

van Leeuwen, L., Quick, S. \& Daniel, K. (2002). The sport spectator satisfaction model: A conceptual framework for understanding the satisfaction of spectators. Sport Management Review, 5, 99-128. doi: 10.1016/S1441-3523(02)70063-6

Vargo, S.L. \& Lusch, R.F. (2006). Service-dominant logic: What it is, what it is not, what it might be. In R.F. Lusch and S.L. Vargo (Eds), The Service-Dominant Logic of Marketing: Dialog, Debate and Directions, (pp. 43-56), New York: M. E. Sharpe Inc. 
Vargo, S.L., Maglio, P.P. \& Akaka, M.A. (2008). On value and value co-creation: a service systems and service logic perspective. European Management Journal, 26,145-152. doi: $10.1016 /$ j.emj.2008.04.003

Wakefield, K. \& Blodgett, J. (1994). The importance of servicescapes in leisure service settings. Journal of Services Marketing, 8, 66-76. doi: 10.1108/08876049410065624

Westerbeek, H. and Shilbury, D. (2003). A conceptual model for sport services marketing research: Integrating quality, value and satisfaction. International Journal of Sports Marketing and Sponsorship, 5, 3-23. doi: 10.1108/IJSMS-05-01-2003-B002

Wolfson, S., Wakelin, D. \& Lewis, M. (2005). Football supporters' perceptions of their role in home advantage. Journal of Sports Sciences, 23, 365-374. doi: $10.1080 / 02640410400021567$

Woratschek, H., Horbel, C. \& Popp, B. (2014). The sport value framework - a new fundamental logic for analyses in sport management. European Sport Management Quarterly, 14, 6-24. doi: $10.1080 / 16184742.2013 .865776$

Yoshida, M., James, J. \& Cronin, J. (2013). Sport event innovativeness: Conceptualization, measurement, and its impact on consumer behaviour. Sport Management Review, 16, 68-84. doi: 10.1016/j.smr.2012.03.003

Zeithaml, V., Bitner, M. \& Gremler, D. (2006). Services Marketing: Integrating Customer Focus across the Firm, New York: McGraw-Hill

Zhang, D., Linderman, K. \& Schroeder, R.G. (2012). The moderating role of contextual factors on quality management practices. Journal of Operations Management, 30, 12-23. doi: 10.1016/j.jom.2011.05.001

Zhao, X., Yeung, A. \& Lee, T.S. (2004). Quality management and organizational context in selected service industries of China. Journal of Operations Management, 22, 575-587. doi: 10.1016/j.jom.2004.08.003 


\section{Figures}

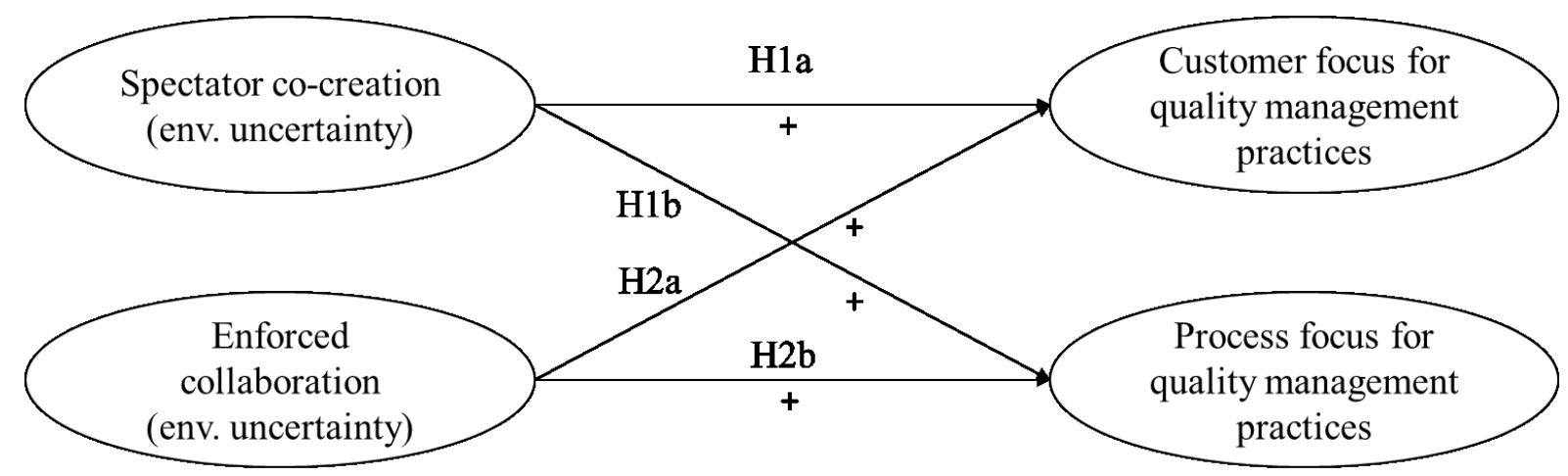

Figure 1 Hypothesized relationships 


\section{Tables}

Table 1 Descriptive statistics of the venues $(n=64-71)$

\begin{tabular}{lclrlll} 
Type of sport & & Ownership & \multicolumn{2}{c}{ Country } & \\
\hline American Football & 1 & Public & 26 & Australia & 5 \\
Basketball & 1 & Private & 43 & Canada & 5 \\
Cricket & 10 & & & New Zealand & 4 \\
Ice hockey & 1 & Venue type & UK & 44 \\
\cline { 2 - 3 } Horse racing & 6 & Indoor & 9 & US & 6 \\
Rugby & 13 & Outdoor & 49 & & \\
Football/ Soccer & 11 & Both & 13 & & \\
Tennis & 4 & & & & \\
Multiple sports & 22 & & & &
\end{tabular}

Table 2 Descriptive statistics of the respondents in the organizations $(n=71)$

Work experience in the sport

\begin{tabular}{lclc} 
industry & \multicolumn{3}{c}{ Athletic background } \\
\hline 0-4 years & 9 & Professional & 7 \\
5-9 years & 13 & Amateur & 43 \\
10-14 years & 14 & None & 21 \\
15-19 years & 15 & & \\
more than 20 years & 20 & &
\end{tabular}


Table 3 Construct and item statistics

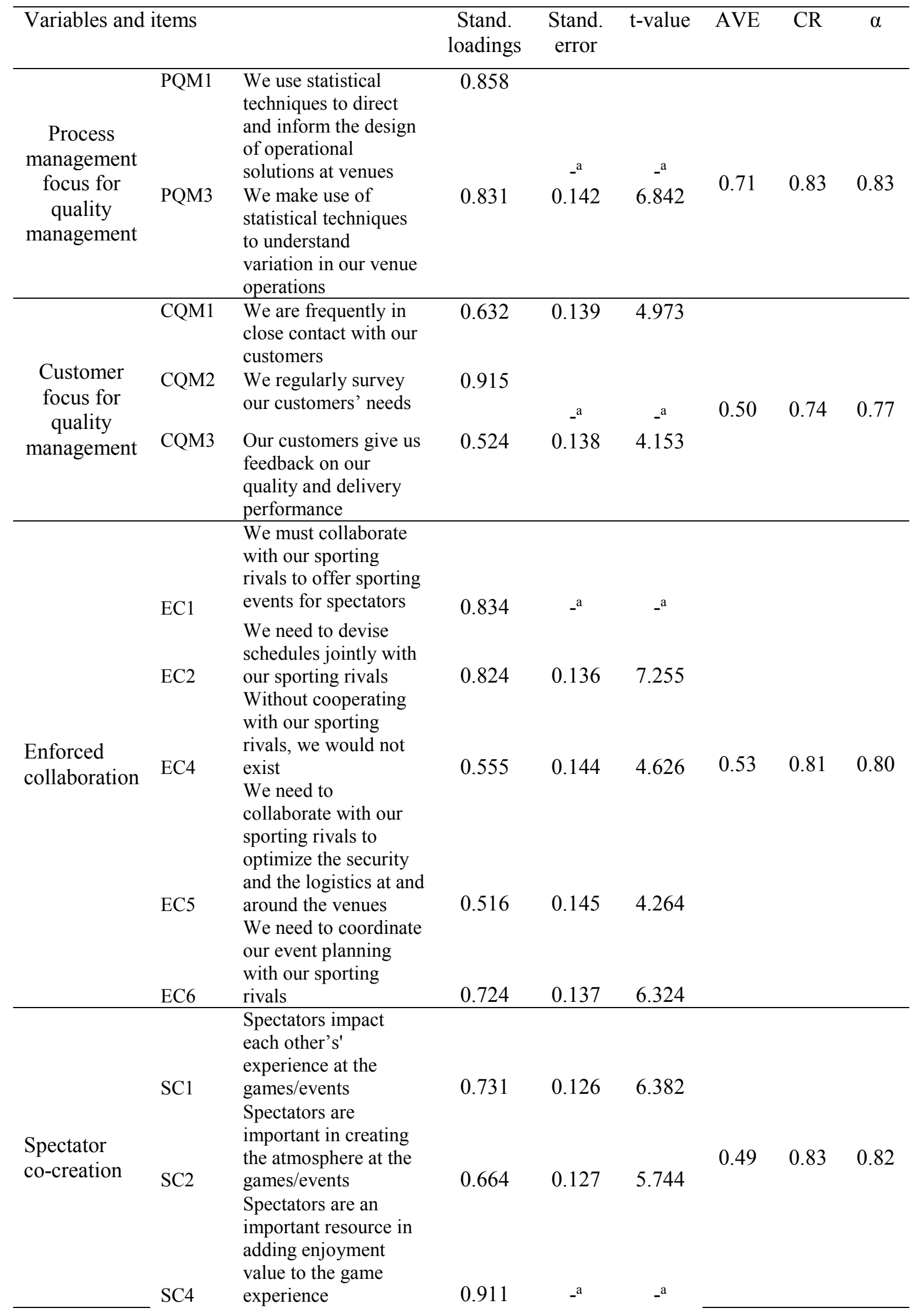




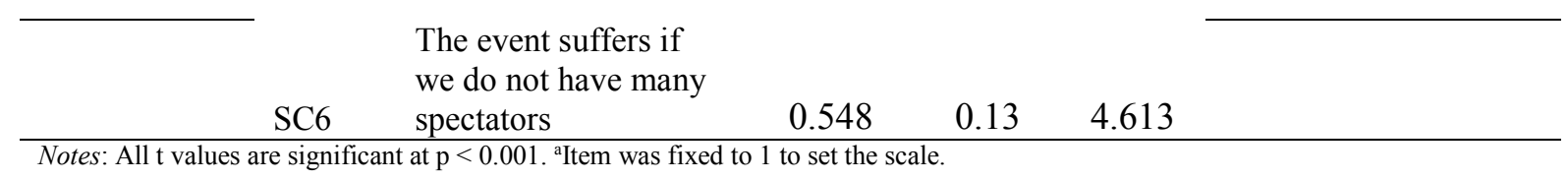

Table 4 Results of regression analysis

Model 1 -

Model 2 -

Process Management

for quality

Customer focus

management

for quality

Constructs

$0.297^{*}$ management

Spectator co-

creation

$-0.238^{\dagger}$

$0.171^{\mathrm{ns}}$

Enforced

collaboration

$0.027^{\mathrm{ns}}$

(Intercept)

Model F

3.151

1.196

$\mathrm{R}^{2}$ 0.09 0.03

$\mathrm{n}=71$. All entries are standardized regression coefficients.

${ }^{\mathrm{t}} \mathrm{p}<0.10,{ }^{*} \mathrm{p}<0.05, \mathrm{~ns}=$ non-significant 


\section{Appendix A - survey items}

Scale: 1-Strongly disagree, 7- Strongly agree

\section{Enforced collaboration}

EC1 We must collaborate with our sporting rivals to offer sporting events for spectators

EC2 We need to devise schedules jointly with our sporting rivals

EC3 We have to co-ordinate with broadcasting and media when organizing our operations

EC 4Without cooperating with our sporting rivals, we would not exist

EC $5 \mathrm{We}$ need to collaborate with our sporting rivals to optimise the security and the logistics at and around the venues

EC6 We need to co-ordinate our event planning with our sporting rivals

EC7 We need to decide on admission pricing together with our sporting rivals

\section{Spectator co-creation}

SC1 Spectators impact each other's experience at the games/events

SC2 Spectators are important in creating the atmosphere at the games/events

SC3 Spectator behavior can complicate event operations

SC4 Spectators are an important resource in adding enjoyment value to the game experience

SC5 We need to manage spectators as partial employees

SC6 The event suffers if we do not have many spectators

SC7 Spectators are important in helping the home team/athlete(s) perform well on-field

Customer focus for quality management

CQM1 We are frequently in close contact with our customers

CQM2 We regularly survey our customers' needs

CQM3 Our customers give us feedback on our quality and delivery performance

Process management focus for quality management

PQM1 We use statistical techniques to direct and inform the design of operational solutions at venues

PQM2 We use charts to visualise and summarise our control of venue operations

PQM3 We make use of statistical techniques to understand variation in our venue operations

\section{Marker variables}

MV1 I regularly use social media for work purposes

MV2 I regularly receive useful information from the national governing body for the main sport at our venue 


\section{Appendix B - Item level scores}

\begin{tabular}{|c|c|c|c|c|}
\hline Item & Min. & Max. & Mean & $\begin{array}{c}\text { Std. } \\
\text { Deviation }\end{array}$ \\
\hline $\begin{array}{l}\text { EC1 We must collaborate with our sporting rivals to offer sporting } \\
\text { events for spectators }\end{array}$ & 1 & 7 & 4,704 & 2,017 \\
\hline EC2 We need to devise schedules jointly with our sporting rivals & 1 & 7 & 4,803 & 1,8254 \\
\hline $\begin{array}{l}\text { EC3 We have to co-ordinate with broadcasting and media when } \\
\text { organizing our operations }\end{array}$ & 1 & 7 & 4,957 & 2,0824 \\
\hline $\begin{array}{l}\text { EC 4Without cooperating with our sporting rivals, we would not } \\
\text { exist }\end{array}$ & 1 & 7 & 3,789 & 2,1308 \\
\hline $\begin{array}{l}\text { EC } 5 \text { We need to collaborate with our sporting rivals to optimise the } \\
\text { security and the logistics at and around the venues }\end{array}$ & 1 & 7 & 4,338 & 1,9636 \\
\hline $\begin{array}{l}\text { EC6 We need to co-ordinate our event planning with our sporting } \\
\text { rivals }\end{array}$ & 1 & 7 & 4,592 & 1,8093 \\
\hline $\begin{array}{l}\text { EC7 We need to decide on admission pricing together with our } \\
\text { sporting rivals }\end{array}$ & 1 & 7 & 3,271 & 1,9555 \\
\hline SC1 Spectators impact each other's experience at the games/events & 1 & 7 & 6,07 & 1,1991 \\
\hline $\begin{array}{l}\text { SC2 Spectators are important in creating the atmosphere at the } \\
\text { games/events }\end{array}$ & 4 & 7 & 6,592 & 0,6671 \\
\hline SC3 Spectator behavior can complicate event operations & 1 & 7 & 5,704 & 1,5982 \\
\hline $\begin{array}{l}\text { SC4 Spectators are an important resource in adding enjoyment value } \\
\text { to the game experience }\end{array}$ & 3 & 7 & 6,211 & 1,0812 \\
\hline SC5 We need to manage spectators as partial employees & 1 & 7 & 3,859 & 1,8462 \\
\hline SC6 The event suffers if we do not have many spectators & 1 & 7 & 5,662 & 1,5761 \\
\hline $\begin{array}{l}\text { SC7 Spectators are important in helping the home team/athlete(s) } \\
\text { perform well on-field }\end{array}$ & 1 & 7 & 5,535 & 1,5197 \\
\hline CQM1 We are frequently in close contact with our customers & 2 & 7 & 5,549 & 1,3394 \\
\hline CQM2 We regularly survey our customers' needs & 1 & 7 & 4,254 & 1,9546 \\
\hline $\begin{array}{l}\text { CQM3 Our customers give us feedback on our quality and delivery } \\
\text { performance }\end{array}$ & 1 & 7 & 5,549 & 1,4715 \\
\hline $\begin{array}{l}\text { PQM1 We use statistical techniques to direct and inform the design } \\
\text { of operational solutions at venues }\end{array}$ & 1 & 7 & 3,239 & 1,9009 \\
\hline $\begin{array}{l}\text { PQM2 We use charts to visualise and summarise our control of } \\
\text { venue operations }\end{array}$ & 1 & 7 & 3,239 & 1,9528 \\
\hline $\begin{array}{l}\text { PQM3 We make use of statistical techniques to understand variation } \\
\text { in our venue operations }\end{array}$ & 1 & 7 & 3,352 & 1,928 \\
\hline
\end{tabular}

